\title{
Paideusis
}

\section{The Social and Educational Vision of Deweyan Pragmatism}

\section{Kathy Hytten}

Volume 10, Number 2, 1997

URI: https://id.erudit.org/iderudit/1073182ar

DOI: https://doi.org/10.7202/1073182ar

See table of contents

Publisher(s)

Canadian Philosophy of Education Society

ISSN

0838-4517 (print)

1916-0348 (digital)

Explore this journal

Cite this article

Hytten, K. (1997). The Social and Educational Vision of Deweyan Pragmatism. Paideusis, 10(2), 33-45. https://doi.org/10.7202/1073182ar viewed online.

https://apropos.erudit.org/en/users/policy-on-use/ 


\section{The Social and Educational Vision of Deweyan Pragmatism}

\section{Kathy Hytten, Southern Illinois University at Carbondale}

Over the past decade, there has been a resurgence of interest in American pragmatism among scholars in a wide range of academic fields. One of the most compelling arguments for pragmatism's rise in popularity is the renewed appeal of pragmatist social thought, particularly in an age of postmodern cynicism and even despair.

Dewey, in particular, was an important public philosopher, influential in both progressive social movements and educational reform. Beginning at the turn of the century with Peirce, James, and Dewey, pragmatist ideas have been significantly influential in American thought. In the dominant narrative of American philosophy, pragmatism was at its heyday during the early 1900 s. Yet, around the 1930s, in conjunction with the rise of analytic philosophy and influences from the continent, pragmatism, particularly its more social and political elements, began to wane. By the middle of the century, citing or claiming pragmatism had become less and less common. For some taken by the analytic movement, even mentioning pragmatism became problematic, implying tender-minded, fuzzy, and rigorless philosophizing. Yet, as the century comes to a close, pragmatism seems to be regaining prominence.

There is no one compelling reason why interest in pragmatism is again on the rise, in part because there has never been consensus as to what is philosophically most significant about pragmatism or, even more basically, how pragmatism can best be defined. Contemporary scholars are attracted for a variety of reasons. Some are lured by pragmatist theories of meaning, others by discussions of truth, and still others by problems of language, knowledge, and interpretation. Discussing the proliferation of recent pragmatist works, Campbell argues that one prominent theme has been attention to more abstract philosophical issues. He sees this as ironic given early pragmatist social commitments and concern with philosophizing relevant to the real life problems of men and women. ${ }^{1}$ He suggests that

... up to now, this interest has generally confined itself to intellectualistic topics-important, but not transcendentally important, topics like Pragmatism's understanding of meaning and truth, its relationship to semiotics and foundationalism, its commitments to naturalism and realism-to the exclusion of Pragmatic social thought. ${ }^{2}$

For Campbell, this exclusion of pragmatist social thought from contemporary discussions of pragmatism is particularly problematic.

While it is true that pragmatist social thought has not been at the forefront of most recent discussions, particularly those among philosophers, the social and political side of pragmatism has not been entirely neglected. Among neopragmatists, Rorty addresses its importance in diminishing cruelty, ${ }^{3}$ Gunn offers pragmatism as supportive of a more critical public culture, ${ }^{4}$ Fraser argues for pragmatic efforts at restructuring society, 5 , and West claims that the key to pragmatism is its ethical commitment to bringing about a more just future. ${ }^{6}$ Nonetheless, pragmatism's social and political vision, thought, and agenda have only just begun to be more prominent, and Campbell argues much work still 
remains to be done. This is particularly true in education where surprisingly few scholars seriously attend to the educational impact of the contemporary crossdisciplinary interest in pragmatism despite the fact that it has been one of the most influential schools of educational philosophy. Equally problematic is the fact that even those educational philosophers who do significant work in pragmatism often remain outside many broader neo-pragmatist discussions.

Given the renewed interest in pragmatism's social project, a detailed examination of Dewey-the social thought of pragmatism's most prolific spokesperson-is vital to understanding pragmatism's current appeal and to situating the works of neo-pragmatists. First, Dewey writes voluminously about social and political issues, and continually argues for philosophers to be actively engaged in the social issues of their day and in efforts at social change. ${ }^{7}$ Yet, even among educators, his more explicitly social writings are still not very well known or analyzed. Second, Dewey argues that all theorizing, even when focused on more 'intellectualistic' concerns, takes place in a social context and, thus, has social and political consequences that always need to be addressed. ${ }^{8}$ Third, Dewey's social vision, whether directly cited or not, informs the work of many neo-pragmatist writers and, hence, understanding how Dewey thought individuals should be and act in the world is integral to contextualizing the contemporary pragmatist movement and characterizing its educational relevance. Finally, it is in his social vision that Dewey most powerfully responds to postmodern challenges as he calls for academics to address social problems and propose visions for a qualitatively better future.

The connection between pragmatism and postmodernism is significant largely because these two modes of philosophizing share many of the same fundamental assumptions, and yet, they end with different orientations toward the world. Both are skeptical of grand theories, argue against the existence of absolutes and foundations, and accept all theories as tentative and provisional. However, unlike many postmodernists, even given this absence of certainty, pragmatists argue that individuals can act with effect in the world and can justify particular moral commitments. This pragmatist faith in the ability of individuals to have a positive influence on the future is intimately connected to their social vision. Several distinctive features set pragmatism apart from other more cynical contemporary social theories. First, pragmatists do not simply describe the world but aim to influence the present and the construction of the future. Second, they have unique views of knowledge, intelligence, and the productive interpenetration between individuals and society. And third, they are guided by inspiring visions of education and democracy. These three themes underlie the contemporarily relevant social vision of pragmatism.

The central theme of Dewey's social thought is reconstruction, challenging anachronistic habits and traditions and creating new ways of dealing with problems on a number of different levels. First, philosophy in general needs reconstruction. Dewey reacts against more traditional views of philosophy as the pursuit of abstract truths and certainties, claiming that philosophers should instead take the lived problems of men and women as their starting point. Second, he argues that reconstruction of the methods of inquiry is essential. Here, he extols the scientific spirit and suggests that philosophers should use the tools of science to address social problems. Connected to this logical reconstruction, Dewey also calls for conceptual reconstruction, proposing that 
each generation has to rethink the meaning of concepts that are central in its social discourse in order for them to remain meaningful. Third, he suggests that educational reconstruction is necessary and that education needs to be more attentive to social and moral issues. Each of these is important to Dewey's more general goal of social reconstruction, of envisioning and creating a better, more socially just future.

\section{Reconstruction of Philosophy}

The need for a rethinking and reconstructing of philosophy underlies all of Dewey's works. In addition to his seminal 1945 essay "The Need for a Recovery of Philosophy," Dewey devotes his entire Reconstruction in Philosophy to this topic, opening with a discussion of experience-an issue of recurring importance to him. Beginning with the idea that what separates men and women from lower animals is the fact that they preserve past experiences through memory, he builds a perspective on the origin of philosophy which be suggests has important contemporary consequences (MW 12: 80)..$^{9}$ One of the distinctive features of human memory, Dewey argues, is that most often it does not involve literal recollection but is imbued with fancy and imagination. Actual facts are not central, but the feelings that they give rise to and the recreation of experience these feelings engender. Being emotional and desiring creatures, people remember things because they find them interesting, because they appeal to listeners, but most significantly, because they are emotionally satisfying and congenial ("the primary life of memory is emotional rather than intellectual or practical" (MW 12: 80) as "the ordinary consciousness of the ordinary man left to himself is a creature of desires rather than intellectual study, inquiry, or speculation" (MW 12: 82)).

Over time, emotionally appealing memories that are recurrent and affect groups of people become "socially generalized" elements of a tradition or story forming "the social heritage and possession" of a group. However, these memories and beliefs are but one element of its generalized social consciousness; they compete with another element of importance-matter-of-fact or prosaic knowledge based on observed facts and sequences of nature. For example, heavy objects fall without support, sharp objects cut, water and food are found in particular places, and natural events have some predictable regularity. Dewey sees these in latter-day terms as more scientific facts since they are based not as much on fancy as on observations.

Both traditional, emotionalized beliefs and more matter-of-fact, scientific beliefs have their attractions. Historically important, Dewey argues, is that these two types of mental products became associated with different social classes with significant consequences for how they were valued. On the one hand, the religious, emotive, and poetic beliefs and ideas became the possession of the higher strata of society, who could claim some sort of special and privileged hold on knowledge and use these selective memories and traditions to support their power and prestige. The lower classes of society, on the other hand, functioned in the realm of more matter-of-fact knowledge. In time, however, their knowledge increased with such intensity and scope that it "came into conflict with not merely the detail but with the temper of traditional and imaginative beliefs" (MW 12: 87). 
Philosophy, Dewey argues, results from the attempt to reconcile these ways of knowing. Matter-of-fact knowledge came to be seen as inferior, a type of knowing which "needs to be controlled by a higher kind of knowledge which will reveal ultimate ends and purposes, and thus put and keep technical and mechanical knowledge in its proper place" (MW 12: 88). Rather than trying to uncover nature's more matter-of-fact secrets, "it became the work of philosophy to justify on rational grounds the spirit, though not the form, of accepted beliefs and traditional customs" (MW 12: 90). This defending and rationalizing what had already been accepted because of its emotional appeal and social prestige had significant consequences. First, it served to justify the distancing of philosophers from more tangible, everyday problems, with philosophers, instead, aiming to extract "the moral kernel out of the threatened traditional beliefs of the past," in order to "conserve and not waste the values wrought out by humanity" (MW 12: 89). Second, it contributed to philosophers' fascination with abstract reasoning. To defend emotionally appealing, though not necessarily empirically verifiable beliefs, philosophers developed a pretentious language of their own characterized by "that appearance of abstract definition and ultra-scientific argumentation which repels so many from philosophy but which has been one of its chief attractions to its devotees" (MW 12: 91). Third, philosophers entrenched a dichotomy between rational and empirical realms of knowing. The emotive realm of ideas and beliefs became ultimately more important as "philosophy arrogated to itself the office of demonstrating the existence of a transcendent, absolute, or inner reality and of revealing to man the nature and features of this ultimate and higher reality" (MW 12: 92). And fourth, it contributed to a schism between theory and practice, with practice viewed as mundane and unenlightened. Philosophers, thus, began to lay claim to "a higher organ of knowledge than is employed by positive science and ordinary practical experience ... marked by a superior dignity and importance" (MW 12: 92). This perspective, Dewey argues, set the stage for philosophers' traditional eschewing of socially useful and responsible roles. Here, Dewey intervenes and argues for a reconstructed role for philosophy in daily life to help uncover social and moral problems and to work towards possible solutions.

Summarizing his reconstructed view of philosophy, Dewey claims, first, in the vein of contemporary postmodern philosophers, that "the transfer of interest from the eternal and universal to what is changing and specific" (MW 12: 106) is central to social theory since it underlies the belief that it is not abstract, timeless truths that philosophers should be seeking, but temporal solutions to pressing social problems. Second, reconstructed philosophy is marked by the "gradual decay of the authority of fixed institutions" and, rather than relying on taken-for-granted or socially prestigious truths, it is sustained by "belief in the power of individual minds, guided by methods of observation, experiment and reflection, to attain the truths needed for the guidance of life" (MW 12: 106). Believing in the power of intelligence and the ability of individuals to affect the world around them in constructive ways, Dewey, foreshadowing postmodern philosophers, rejects absolutes and supposedly fixed certainties. Third, he emphasizes the key role that consideration of the future plays in understanding and living most well in the present ("the future rather than the past dominates the imagination" (MW 12: 106)). Together, these three attributes of a reconstructed philosophy point to a view of the role of 
philosophers in public life sustained by belief in their "power to direct nature's forces through knowledge-that is, purposeful, experimental action acting to reshape beliefs and institutions" (MW 12: 108). To actualize his vision of a socially relevant philosophy, Dewey proposes a second level of reconstruction, that of inquiry and logic, the methods by which individuals come to understand and know the world around them.

\section{Knowledge, Inquiry and Wisdom}

For Dewey, the gateway to knowledge is experience, the interaction of organisms with their environment. Fundamentally, humans are sentient beings who receive stimulation from the world around them. These sensations cause individuals to act and react, and are "provocations, incitements, challenges to an act of inquiry," inquiry which then can lead to knowledge of various situations and contexts (MW 12: 131). Experience stimulates inquiry, leads to knowledge, and culminates in wisdom, which he defines as "knowledge operating in the direction of powers to the better living of life" (MW 6: 221).

Primary experiences are the everyday, untheorized, crude interactions individuals have with the world around them-fundamentally felt or sensed. In secondary experience, individuals reflect on and abstract from these primary experiences. The essence of this distinction is "between what is experienced as a the result of a minimum of incidental reflection and what is experienced in consequence of continued and regulated reflective inquiry" (LW 1: 15). Dewey argues that science and philosophy both result from reflection upon primary experiences but, beyond this connection, they diverge because "the natural sciences not only draw their material from primary experience, but they refer it back again for test" (LW 1: 15). It is this step of returning to primary experience that philosophers often do not take, resting content with abstract understandings far removed from the objects of primary experience. The resulting philosophies often do not resonate with how individuals experientially understand the world, contributing to the seemingly irrelevant nature of much of traditional philosophy.

According to Dewey, what is important about experience is that it stimulates inquiry, the effort that individuals make to understand and reconstruct the world around them. The appeal to scientific inquiry, in which the unification of primary and secondary experiences is central, is the key to understanding how Dewey thinks individuals should be in the world and how they should attack physical, social, political, and moral problems. His attraction to science is methodological and attitudinal. He places "the emphasis in using the term 'scientific' first upon methods"' (MW 3: 3), "systematic methods of inquiry, which, when they are brought to bear on a range of facts, enable us to understand them better and to control them more intelligently, less haphazardly, and with less routine" (LW 5: 4). Scientific attitude is equally important and can be characterized as "the will to inquire, to examine, to discriminate, to draw conclusions only on the basis of evidence after taking pains to gather all available evidence' (LW 13: 273).

Dewey succinctly defines inquiry as "the controlled or directed transformation of an indeterminate situation into one that is so determinate in its constituent distinctions and relations as to convert the elements of the original situation into a unified whole" (LW 12: 108). This inquiry involves several 
steps. First, there is situation of indeterminacy or confusion, where a routine or habit is disrupted. Second, there is an attempt to determine the problem: the "intellectualization of the difficulty or perplexity that has been felt (directly experienced) into a problem to be solved, a question for which the answer must be sought" (LW 8: 200). Third, the problem is examined more carefully and potential solutions imagined, as well as hypotheses to test them. Fourth, the hypothetical solutions are more elaborately examined through tests in which the consequences of various solutions to problems are projected. Fifth, actual experimental testing of the most promising hypothetical solutions occurs.

For Dewey, what is important about these steps to inquiry is that they are thoughtful, systematic, thorough and, more significantly, involve the projection of potential solutions and action upon the most reasoned and refined hypotheses. His primary concern is not the results of inquiry, but the method of attacking problems and the logical reconstruction of the situation. At heart, Dewey thinks individuals are reflective and responsive, capable of coming up with solutions to even the most pressing problems. Through inquiry and reflective thought, individuals can "transform a situation in which there is experienced obscurity, doubt, conflict, disturbance of some sort, into a situation that is clear, coherent, settled, harmonious"' (LW 8: 195). Furthermore, systematic inquiry leads to knowledge of the world and contributes to the development of human intelligence.

Dewey's view of knowledge reacts against a "picture" or "spectator" view, suggesting instead that knowledge is a matter of the interaction between individuals and their environment and arises from the effort to transform problematic situations into settled ones. In the spectator view, "the knower, however defined, is set over and against the world to be known," and "knowing consists in possessing a transcript, more or less accurate but otiose, of real things" (MW 10: 41). In contrast, Dewey argues that knowing involves projecting future consequences and determining the most effective ways of dealing. with past experience. Thus, intelligence entails reacting to doubtful situations with thoughtful and systematic inquiry. Knowing involves both relating the elements of inquiry to previous inquiries and determining the connections between past experiences and present problems.

Dewey describes this connection succinctly in Democracy and Education:

[W] hile the content of knowledge is what has happened, what is taken as finished and hence settled and sure, the reference of knowledge is future or prospective. For knowledge furnishes the means of understanding or giving meaning to what is still going on and what is to be done. (MW 9: 351).

Knowledge of the past is useful in that it gives individuals a critical tool with which to help understand and forecast the future; knowing is a matter of the use that is made of experiences in dealing with problems and bringing about an envisioned future. Out of understanding this interconnection between past, present, and future, Dewey argues, wisdom arises. Wisdom is not gathering, codifying; and amassing knowledge but "refers to a choice about something to be done, a preference for living this sort of life rather than that. It refers not to an accomplished reality but to a desired future which our desires, when translated into articulate conviction, may belp bring into existence" (MW 11: 44). Elsewhere, he suggests that wisdom is "the application of what is known to 
intelligent conduct in the affairs of human life" (LW 15: 157) with the ultimate goal of meaningful social reconstruction.

\section{Social Reconstruction}

Social reconstruction is a central theme in Dewey's writings. His overriding message is that ideas, knowledge, and thought in general are essentially preparations for action. He steadfastly maintains that "ideas are worthless except as they pass into actions which rearrange and reconstruct, in some way, be it little or large, the world in which we live" (LW 4: 111). Furthermore, he outlines the types of changes necessary to bring about a more enriching life for all people. These include engaging individuals in persistent and ongoing inquiry into moral and social problems, meaningfully attending to the intimate connections between individuals and the community, and fostering the development of genuine democracy. ${ }^{10}$

Methodologically, social reconstruction parallels inquiry, beginning with a societal problem, issue, or concern. It first involves articulating the problem, formulating its dimensions, and imagining possible solutions. The merits and drawbacks of different solutions can then be thoroughly examined, discussed, and debated in some organized manner and in light of what is best for the society. From there, proposed solutions are decided. Then, after these changes are tried, they can be evaluated for their effectiveness and, if they seem to address the problem successfully, turned into laws or practices. Dewey's concern is that individuals do not attend to social issues nearly enough in this organized manner, letting themselves be guided by impulses, emotions, and thoughtless adherence to past habits and traditions, instead of by systematic and hypothetical thought. Social reconstruction requires bringing "into any inquiry into human and moral subjects the kinds of method (the method of observation, theory as hypothesis, and experimental test) by which understanding of physical nature has been brought to its present pitch" (MW 12: 258). All members of society are involved in this process, but philosophers, because of their unique abilities to clarify and critique ideas, should play key roles in deepening and refining society's understanding of social problems. Indeed, for Dewey, "the specific problem of philosophical reconstruction at the present time ... [is] social deficiencies that require intelligent diagnosis, and projection of aims and methods" (MW 12: 153).

For Dewey, all social problems are equally moral problems since they emerge from the interaction of individuals. Applying the methods of inquiry derived from the physical sciences to moral issues contributes to the "construction of a moral human science which serves as a needful precursor of reconstruction of the actual state of human life toward order and toward other conditions of a fuller life than man has yet enjoyed" (MW 12: 274) so "that the traditional barriers between scientific and moral knowledge be broken down, so that there will be organized and consecutive endeavor to use all available scientific knowledge for humane and social ends" (LW 7: 283).

As part of social reconstruction, Dewey argues that conceptions such as individuality, social justice, community, freedom, equality, and democracy are always in process, and need to be continually reconsidered in order to hold meaning for each generation. They should be thought of "as hypotheses to be employed in observation and ordering of phenomena, and hence to be tested by 10(2), Spring, 1997 
the consequences produced by acting upon them" and not "as truths already established and therefore unquestionable" (LW 12: 499). To achieve the fuller life that Dewey envisions, two ideas especially need rethinking: democracy and the connection between the individual and the community. He argues that effective social change requires both an understanding of individuals as inherently social creatures and a view of democracy which pervades all social life and is premised on faith in the capacities of individuals for reflective thought, intelligent judgment, co-operative social inquiry, and meaningful social change.

Dewey holds that individuals are social beings whose thoughts, actions, and well-beings are tied to those around them.

Every individual has grown up, and always must grow up, in a social medium ... through social intercourse, through sharing in the activities embodying beliefs, he gradually acquires a mind of his own. The conception of mind as a purely isolated possession of the self is at the very antipodes of the truth. (MW 9: 304)

Intelligence is not solely an individual possession; individual strengths and contributions are stimulated and emerge from association with others. Through working together in efforts to solve social problems in a process that all contribute to, sincere socially engaged thought and action will lead to positive social reconstruction which enriches life for all people. Dewey denies that knowledge, discoveries and progress in general are the result of the accomplishments of single individuals. The relationship between individuals and the community is interpenetrating: "The individual in his isolation is nothing, only in and through an absorption of the aims and meaning of organized institutions does he attain true personality" (MW 9: 101). Moreover, "to learn to be human is to develop through the give-and-take of communication an effective sense of being an individually distinctive member of a community; one who understands and appreciates its beliefs, desires, and methods, and who contributes to a further conversion of organic powers into human resources and values"' (LW 2: 332).

An individuality which "is intelligently alive to the common life and sensitively loyal to its common maintenance" (MW 11: 57) is essential for the creation of a genuine democratic society-Dewey's ideal society. For him, "a democracy is more than a form of government; it is primarily a mode of associated living, of conjoint communicated experience" (MW 9: 93, see also LW 2: 328 ) which continually needs to be explored. True community involves dialogue, give and take, the sharing of ideas and experiences, and co-operative undertakings. The characteristics which Dewey describes as marking democracy are common interests, free and varied interactions, and co-operative efforts at making the society more humane and more liveable. In short, "the foundation of democracy is faith in the capacities of human nature; faith in human intelligence and in the power of pooled and co-operative experience. It is not belief that these things are complete but that, if given a show, they will grow and be able to generate progressively the knowledge and wisdom needed to guide collective action" (LW 11: 219).

Democracy, as a "way of life controlled by a working faith in the possibilities of human nature" which includes faith "in the capacity of human beings for intelligent judgment and action" is the central aim of continual social reconstruction (LW 14: 226-7). It is not an end in-and-of-itself which can be 
achieved once and for all but something to be rebuilt with each generation. Yet, Dewey consistently maintains that if scientific methods of inquiry are diligently applied to social issues and if individuals see it as their role as members of society to engage in co-operative efforts at social reform, positive social reconstruction will result. He calls for systematic thought and imagination about what constitutes a fulfilled life and action to bring that about. Action is pivotal as consequences determine the quality of particular social actions and choices: "What is needed is intelligent examination of the consequences that are actually effected by inherited institutions and customs, in order that there may be intelligent consideration of the ways in which they are intentionally modified in behalf of generation of different consequences" (LW 4: 218). These different consequences include bringing about greater social justice, more opportunities for individuals to contribute to society, and the flourishing of individual capacities leading to the growth and enrichment of society as a whole.

Reconstruction of philosophy, knowledge, inquiry, concepts, and society in general are all linked by an additional overarching theme that most direction attends to the question of how-that is, reconceptualization and reconstruction of education. For Dewey, "education is the fundamental method of social progress and reform" (WE 5: 93) and "the most far-reaching and most fundamental way of correcting social evils and meeting social issues" (LW 5: 297).

\section{Reconstruction of Education}

Consistently in Dewey's thought, philosophy, education, and democracy are intimately linked: the reconstruction of philosophy, education, inquiry, and society are all integral elements of social change. Their connection emerges from his understanding of education in general. Dewey argues that education involves the formation of the habits and attitudes necessary for life-long learning and for both individual and social growth. Education is about the reconstruction of experience in ways which help illuminate the past, clarify the present, and bring about a desired and envisioned future. Dewey reacts against several meanings of education which are often posited or taken for granted. First, education is not about preparation for the future or for some specific future career or occupation. While the future is a consideration in present choices, individuals live in the present; thus, education should be about "making the present experience as rich and significant as possible" (MW 9: 61) as "education . . . is a process of living and not a preparation for future living" (WE 5: 87). Second, education is not about the unfolding or awakening of latent individual capacities or about the training of particular mental or physical abilities of individuals in the abstract. Dewey argues that there are no such capacities; rather, the wise use of the mind is a learned behavior. Third, education is not about the transmission of objective facts or the recapitulation of past events. While knowledge of the past is important, it is important only as it is connected to present endeavors.

Consistent with the theme of reconstruction, Dewey defines education as "that reconstruction or reorganization of experience which adds to the meaning of experience, and which increases ability to direct the course of subsequent experience" (MW 9: 82). Thus, education should be about making present experience more meaningful since "we always live at the time we live and not at some other time, and only by extracting at each present time the full meaning 
of each present experience are we prepared for doing the same in the future" (LW 13: 29-30). Meaning, he argues, involves the ability to see knowledge not in isolated pieces but in intimate connection with other things, "the increased perception of the connections and continuities of the activities in which we are engaged" (MW 9: 82-83). These connections and continuities qualify experiences as educative: they foster growth, the ability to see experiences as connected to past occurrences, and the ability to bring about intended outcomes. Furthermore, they promote the capacity to develop, learn from experience, acquire habits of learning, form new purposes and goals, see the connections among ideas, and understand the intimate relationship between knowledge and conduct. The most valuable education creates both the desire and the conditions for growth.

According to Dewey, education should nurture the ability to "direct the course" of future experiences: it should help individuals harness experiential knowledge in order to bring about an envisioned future and more meaningful and connected experiences. Herein is the link between education and social reform: "through education society can formulate its own purposes, can organize its own means and resources, and thus shape itself with definiteness and economy in the direction in which it wishes to move" (WE 5: 94). As part of the goal of directing future experiences, one aim of education should be reflective thought, involving examination of complexity, and systematic evaluation of ideas and proposals, not uncritical acceptance of presented knowledge and facts. Second, education should foster intelligent judgment and the application of scientific methods of observation, hypothesis, experiment and tentative conclusion to social problems. It should "cultivate the habit of suspended judgment, of skepticism, of desire for evidence, of appeal to observation rather than sentiment, discussion rather than bias, inquiry rather than conventional idealizations" (MW 13: 334). Third, education should contribute to the creation of a democratic public. Through education, individuals develop a sense of social life and community. Schools, in particular, must provide the young with "an understanding of social needs and of the resources that may be used to satisfy them" in order to "meet the challenge of democracy" (LW 11: 183). And fourth, intimately connected to the creation of a democratic public, education should promote social consciousness and habits of thinking that result in intelligent social action. Ultimately, "education is a regulation of the process of coming to share in the social consciousness; and that adjustment of individual activity on the basis of this social consciousness is the only sure method of social reconstruction" (WE 5: 93). It must support individual recognition of social aims, the development of values necessary to living adequately and fulfillingly with others, awareness of the necessity of active participation in efforts at social reform and change, and belief in the possibilities of social growth and progress.

While Dewey does not think that education is the sole means by which society can be reconstructed, it has the most potential because schooling entails the development of dispositions and attitudes central to democratic social life and because educators have the power to shape educational experiences in certain ways. If the young are taught to think systematically, to examine continually the potential consequences of hypotheses and choices, to view education as a life-long pursuit, to evaluate the impact of their actions upon others, to examine and critique ideas and proposals thoughtfully, and to imagine and 
project better ways of being in the world, then they will develop these as habits to carry into their adult lives. In the end, Dewey argues, education can make individuals more socially conscious and communally committed and more capable and apt to take an "active part in aggressive participation in bringing about a new social order" (LW 9: 182).

\section{Pragmatist Social Thought}

Given the growing impact of pragmatism on today's social and intellectual scene and its potential to respond to some of the challenges of postmodemism, it is essential that educators rethink this tradition. Reassessing the social vision of pragmatism is integral to this task, especially since it offers a vision for how individuals can constructively influence their future. The most significant theme in Dewey's thought is that philosophy which is abstracted from concrete social problems and concerns is not only misguided, but largely irrelevant. Instead, philosophers should be engaged in social evaluation, reconstruction, and criticism. He maintains that philosophy is "a generalized theory of criticism" (LW 1: 9). Yet, this criticism must also be constructive. Dewey's work can, thus, be seen as a call for a socially engaged philosophy that attends to real problems, to how the youth of society should be educated to be in the world and to making the world better. "Philosophy must in time become a method of locating and interpreting the more serious of the conflicts that occur in life, and a method of projecting ways for dealing with them: a method of moral and political diagnosis and prognosis" (MW 4: 13). Despite his optimism, he is not naive. He realizes that education is not going to save the world, yet he knows that how society educates its youth has significant consequences:

Progress is not inevitable, it is up to men as individuals to bring it about. Change is going to occur anyway, and the problem is the control of change in a given direction. (LW 14:113)

Overall, what shines through his pragmatist philosophy are his experimentalism, his idealism, and his commitment. Because the world is in process, no answers to problems are good for all time. Thus, individuals need to take an experimental stance toward the world and test social solutions they envision, even at the risk of failure. He is extremely wary of a pessimism that inhibits action:

[T]he task is to go on, and not backward, until the method of intelligence and experimental control is the rule in social relations and social direction. Either we take this road or we admit that the problem of social organization in behalf of human liberty and the flowering of human capacities is insoluble. (LW 11: 64)

This faith in the possibility of positive social change and betterment is a theme that is picked up by many contemporary neo-pragmatists. In a time when cynicism and skepticism-often emerging from postmodem orientations toward the world-are pervasive, pragmatism offers an alternative. Despite a view of the world (as in flux, changing, and essenceless) that is comparable to postmodernism, pragmatists retain moral visions, ethical hopes, and a faith in the abilities of common men and women. These emerge in part from their democratic sensibilities but also from the pragmatist commitment to coupling deconstruction of past philosophizing and tradition with social reconstruction 
and action. This commitment to reconstruction is distinctive in our postmodern era. Boisvert captures this idea, suggesting it serves to combat more pervasive cynicism in spite of parallels to postmodern tendencies:

[D]econstructionism is the latest European fashion to influence American intellectuals. Dewey was already a deconstructionist of sorts in the 1920s. His endeavor to indicate the limitations imposed by prior assumptions, his deconstructing of the 'modern,' Cartesian-influenced map, his eschewing of quests for certainty, his recognition that all formulations are tentative and hypothetical-all fall within the deconstructionist enterprise. But Dewey avoided the nihilistic overtones of some deconstructionists by suggesting the need for constant reconstruction as the work of intelligence coming up with answers to what he called the 'problems of men."11

In this commitment to social action, reconstruction and reform-the legacy of Dewey-is as relevant to educators today as it was at the beginning of this century.

\section{Notes}

1James Campbell (1992), The Community Reconstructs: The Meaning of Pragmatic Social Thought (Urbana: University of Illinois Press).

2Ibid, p. 1.

${ }^{3}$ Richard Rorty (1989), Contingency, Irony and Solidarity (Cambridge: Cambridge University Press).

${ }^{4}$ Giles Gunn (1992), Thinking Across the American Grain: Ideology, Intellect and the New Pragmatism (Chicago: University of Chicago Press).

5 Nancy Fraser (1989), Unruly Practices: Power, Discourse and Gender in Contemporary Social Theory (Minneapolis: University of Minnesota Press).

${ }^{6}$ Cornel West (1993), Keeping Faith: Philosophy and Race in America (New York: Routledge).

${ }^{7}$ Sleeper captures this theme in Dewey concisely: "Dewey argued that philosophy should have an impact on the world. He thought the critical work of philosophy should have consequences in the conduct of our lives and in the culture in which we live. He wanted us to see that philosophy has the power to influence social change through criticism and inquiry. It is this conception of philosophy that drew Dewey to pragmatism and that comprises his distinctive contribution to it." [From R.W. Sleeper (1986), The Necessity of Pragmatism: John Dewey's Conception of Philosophy (New Haven: Yale University Press), p. ix.]

${ }^{8}$ Writing about this idea, Frankel suggests that Dewey saw philosophy as a "civic enterprise," and "at bottom social philosophy implicitly or explicitly" (p. 5). [From Charles Frankel (1977), "John Dewey's Social Philosophy," in Steven M. Cahn (Ed.), New Studies in the Philosophy of John Dewey (Hanover, NH: The University Press of New England), pp. 3-44].

${ }^{9}$ All references to Dewey's work in this text will be cited according to his collected works. See Jo Ann Boydston (Ed.), The Early Works of John Dewey, 1882-1898, 5 vols; The Middle Works of John Dewey, 1899-1924, 15 vols; and The Later Works of John Dewey, 1925-1953, 17 vols. (Carbondale, IL: Southern Illinois University Press, 1969-1991). 
${ }^{10}$ Here, Dewey is particularly concerned with making sure that theory and practice are intimately connected and that intelligence has a key role to play in social reconstruction. Boisvert claims that "what Dewey wished most of all was to eliminate this gap between learning and affairs. Pragmatism was meant to indicate the continuity between the two, to focus on intelligence in the Greek sense of phronesis, wisdom used to guide behavior . . . intelligence had as its task not the apprehension of standards already set forth and given prior to cognition, but the actual creation or construction of new goods or ends" (p. 348). [From Raymond D.Boisvert (1985), John Dewey's Reconstruction of Philosophy, Educational Studies, 16(4), pp. 343-353].

${ }^{11}$ Ibid., p. 345. 